\title{
PERLINDUNGAN HAK NARAPIDANA WANITA YANG MENGANDUNG DI LAPAS KELAS II B CIANJUR
}

\author{
${ }^{1}$ MitroSubroto, ${ }^{2}$ Agung Sukmawijaya \\ ${ }^{12}$ Politeknik Imu Pemasyarakatan \\ ${ }^{1}$ E-Mail: subrotomitro007@gmail.com \\ ${ }^{2} E-M a i l$ sukmawijayaagung53@gmail.com
}

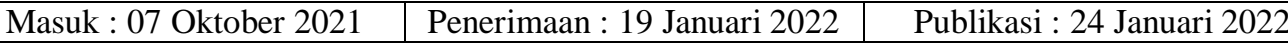

\begin{abstract}
ABSTRAK
Sistem Pemasyarakatan adalah upaya pembinaan yang dilaksanakan di Lembaga pemasyarakatan di Indonesia, pembinaan tersebut ditujukan bagi warga binaan yang melakukan tindak pidana dan dijatuhi hukuman penjara. Dalam proses pembinaan tersebut warga binaan diayomi dan dibina oleh petugas pemasyarakatan dan dilindungi hak-haknya sebagai warga negara. Dalam pelaksanaan peraturan-peraturan yang memuat ide-ide pemasyarakatan, maupun di dalam pelaksanaan Undang-undang Pemasyarakatan aparat pelaksana menjalankan tugas berdasarkan peraturan yang berlaku, di mana dalam kondisi tertentu aparat pelaksana mengambil keputusankeputusan yang disesuaikan dengan kondisi dan situasi, agar ide-ide pemasyarakatan tersebut tetap dapat terwujud. Dalam pelaksanaan peraturan-peraturan tersebut banyak kendala-kendala yang menghambat terwujudnya tujuan pemasyarakatan. Kenadalakendala tersebut ada yang dikarenakan keberadaan undang-undang itu sendiri, Dalam peraturan perundang-undangan khususnya dalam Undang-undang Nomor 12 tahun 1995 tentang Pemasyarakatan, ternyata masalah perlindungan hukum terhadap narapidana wanita belum diatur. Karena dalam undang-undang tersebut hanya disebutkan narapidana saja, tidak dibedakan antara narapidana laki-laki maupun Wanita. Sehingga perlu ditelaah ulang bagaimana Undang-Undang Pemasyarakatan melindungi hak-hak terhadap narapidana wanita khususnya bagi yang sedang mengandung.
\end{abstract}

Kata Kunci ： Hak; Mengandung; Narapidana; Perempuan; Perlindungan.

\section{ABSTRACT}

The Correctional System is a coaching effort carried out in correctional institutions in Indonesia, the guidance is intended for inmates who commit criminal acts and are sentenced to prison. In the coaching process, the inmates are protected and nurtured by correctional officers and their rights are protected as citizens. In the implementation of regulations that contain correctional ideas, as well as in the implementation of the Correctional Law, the implementing officers carry out their duties based on the applicable regulations, where under certain conditions the implementing officers make decisions that are adapted to the conditions and situations, so that ideas the correctional idea can still be realized. In the implementation of these regulations, there are many obstacles that hinder the realization of the correctional goals. These obstacles are caused by the existence of the law itself. In the legislation, especially in Law Number 12 of 1995 conceming Corrections, it tums out that the problem of legal protection for female prisoners has not been regulated. Because the law only mentions convicts, it does not differentiate between male and female prisoners. So it is necessary to review how the 
Correctional Law protects the rights of female prisoners, especially those who are pregnant.

Keywords ～: Right; Contain; Prisoners; Woman; Protection.

\section{A. PENDAHULUAN}

Dalam Undang-Undng Nomor 12 Tahun 1995 Tentang Pemasyarakatan, sebagai manusia narapidana memiliki hak yang wajib dihormati dan dijunjung tinggi oleh negara, pemerintah, masyarakat dan hukum. Setiap orang berhak memiliki kehormatan serta perlindungan harkat dan martabat termasuk hak untuk tidak disiksa atau diperlakukan tidak manusiawi yang diatur dalam Konvensi Internasional No. 15 Tahun 2015 Tentang Hak Sipil dan Hak Politik, pada Pasal 7 menyatakan tidak ada seorangpun yang boleh menjadi sasaran penyiksaan, penindasan dan perlakuan tidak manusiawi serta penghukuman lain yang merendahkan harkat dan martabat manusia. Dalam Undang-Undang Dasar 1945 Pasal 28 A juga diatur bahwa setiap orang berhak untuk hidup serta berhak mempertahankan hidup dan kehidupannya (Samosir, 2016).

Perubahan sistem kepenjaraan menjadi sistem pemasyarakatan yang dimulai pada tahun 1964 (Ismail Pettanase, 2019; Sulhin, 2010; Suwarto, 2007). Perubahan ini bertujuan agar terjadi perubahan pandangan bahwa penghukuman yang dijatuhkan pada para narapidana bukan suatu tindakan balas dendam dari negara, melainkan upaya untuk membimbing mereka agar pada saat mereka dibebaskan mereka dapat kembali hidup dan membaur sebagai mana masyarakat pada umumnya (Fatony, 2015). Dalam pelaksanaannya sistem pemasyarakatan melangsungkan pembinaan terhadap narapidana guna memperbaiki pribadi narapidana. Pembinaan tersebut bersifat material, spritual dan keterampilan kepada para narapidana. Pembinaan merupakan suatu tindakan atau usaha dalam bentuk kegiatan yang dilakukan secara efisien dan juga efektif agar mempunyai karakter kepribadian yang lebih baik daripada sebelumnya (Ramadhani et al., 2016). Sedangkan menurut Peraturan Pemerintah Republik Indonesia Nomor 31 tahun 1999 Tentang Pembinaan Dan Bimbingan Warga Binaan Permasyarakatan, dalam Pasal 1 angka (1) menjelaskan, pembinaan adalah kegiatan untuk meningkatkan kualitas terdakwah kepada tuhan yang maha esa, intelektual, sikap dan perilaku, professional, kesehatan jasmaniidan rohani narapidana serta anak 
didik permasyarakatan. Tentang pembinaaan Narapidana di Indonesia, tidak lepas dari mekanisme pembangunan serta kondisi dan pola pikir masyarakat, itu harus diingat bahwa disatu pihak, pemerintah melalui lembaga pemsyarakatan, berusaha membina narapidana. Sedangkan proses pembinaan narapidana selama proses pemasyarakatana merupakan suatu kesatuan yang integral menuju tujuan mengembalikan narapidana ke masyarakat bebas dengan bekal kemampuan (mental, fisik, keahlian, keterampilan, terdapat kemungkinan juga finasial dan materil) yang dibutuhkan menjadi warga yang baik dan berguna (Samosir, 2016). Saat seorang narapidana dijatuhkan vonis oleh pengadilan maka hak-haknya sebagai warga negara akan dibatasi. Seorang narapidana hak terhadap kemerdekaannya tentunya hilang karena kebebasan dalam bergerak dibatasi oleh tembok-tembok yang ada di lapas akan tetapi meskipun hak kemerdekaannya hilang tetap saja hak-hak lain harus dilindungi dalam system Pemasyarakatan Indonesia.

Sesuai dengan Pasal 36 ayat (1) Gestichtenreglement (Ordonasi 10 Desember 1917 No, 708), Indonesia menerapkan pemisahan antara tahanan pria dan wanita (Rusydi, 2021). Jane C. Ollenbburger menyatakan bahwa perempuan melakukan lebih sedikit kejahatan dibandingkan dengan laki-laki (Rusydi, 2021; Sumarauw, 2013). Menurut Hurwitz, hal ini disebabkan oleh beberapa hal, yaitu fisik wanita yang umumnya kurang kuat dan adanya gangguan mental yang khas, serta kondisi lingkungan yang terlindungi, dimana banyak wanita bekerja di rumah untuk menghindari konsumsi alkohol (Fatony, 2015). Pandangan yang kini mulai berubah, tidak dapat disangkal bahwa masyarakat, baik secara sadar maupun tidak sadar, selama ini masih bersikap selektif mengabaikan narapidana perempuan. Kondisi sosial budaya masyarakat melihat perempuan sebagai manusia yang memiliki perasaan lembut, lembut dan jauh dari kekerasan. Jadi ketika seorang wanita melakukan kejahatan, masyarakat menganggap bahwa dia telah melanggar kodratnya sebagai wanita yang baik.

Dalam hal ini yang disebut narapidana wanita atau di sebut warga binaan perempuan di dalam Lembaga Pemasyarakatan Kelas II B Cianjur dan Lembaga Pemasyarakatan lain memiliki kebutuhan-kebutuhan yang berbeda dari laki-laki, seperti, misalnya seorang wanita akan mengalami siklus menstruasi sehingga 
masalah kebersihan menjadi hal yang perlu mendapat perhatian lebih. Selain itu, narapidana yang sedang hamil atau akan melahirkan juga membutuhkan perawatan khusus untuk menjamin kesehatan ibu dan anak. Ketika anak itu lahir, wanita itu juga bisa menyusui. Dalam situasi ini, terlihat adanya perbedaan antara perempuan dan laki-laki yang menuntut perlakuan yang berbeda pula antara keduanya. Namun dalam praktiknya, sayangnya, lembaga pemasyarakatan tidak mencerminkan perbedaan tersebut, sehingga hak perempuan atas pemenuhan kebutuhan khusus tidak terlindungi. Tanpa fasilitas yang memadai. Narapidana perempuan tidak hanya dibatasi haknya sebagai narapidana pada umumnya, tetapi juga mengalami kesulitan ketika harus menghadapi kondisi yang menjadi kodratnya sebagai perempuan. Meski konsep yang dikembangkan Indonesia adalah pembinaan dan bukan retribusi, namun pemerintah harus lebih memperhatikan kebutuhan khusus perempuan ini.

Persoalannya saat ini adalah apakah hak-hak narapidana perempuan dilindungi dengan baik sebagaimana diatur dalam Undang-Undang Nomor 12 Tahun 1995. Sementara itu, Undang-Undang Pemasyarakatan tidak secara khusus memberikan perlindungan hukum bagi narapidana perempuan, padahal karakter narapidana perempuan dan laki-laki adalah sangat berbeda baik secara psikis maupun fisik. Idealnya, penempatan narapidana pria dan narapidana wanita harus dipisahkan. Tujuan pendirian Lembaga Pemasyarakatan Kelas II B Cianjur adalah untuk memisahkan narapidana laki-laki dan perempuan karena alasan keamanan dan psikologis.

Pengaturan mengenai pelaksanaan hak narapidana wanita tertuang dalam peraturan pemerintah Nomor : 32 Tahun 1999 Tentang Syarat Dan Tata Cara Pelaksanaan Hak Warga Binaan Pemasyarakatan dalam Pasal 20 mengatur perlindungan terhadap narapidana wanita yang berbunyi antara lain:

1. Narapidana dan Anak Didik Pemasyarakatan yang sakit, hamil, dan menyusui berhak mendapat makanan tambahan sesuai dengan petunjuk dokter

2. Makanan tambahan juga diberikan kepada narapidana yang melakukan jenis pekerjaan tertentu 
3. Anak dari narapidana yang dibawa kedalam LAPAS ataupun yang lahir di LAPAS dapat diberi makanan tambahan atas petunjuk dokter, paling lama sampai berumur 2 (dua) tahun.

4. Dalam hal anak sebagaimana dimaksud dalam ayat 3 telah mencapai umur 2 (dua) tahun, harus diserahkan kepada bapaknya atau senak keluarga, atau pihak lain atas persetujuan ibunya dan dibuat dalam berita acara.

5. Untuk kepentingan kesehatan anak, kepada LAPAS dapat menentukan makanan tambahan.

\section{B. METODE}

Penelitian ini menggunakan metode penelitian normatif dengan melakukan penelusuran kepustakaan. Hasil penelitian ini diperoleh bahan hukum berupa undang-undang, pendapat ulama dan tulisan tentang penyelesaian hukum. dalam penelitian adalah metode kepustakaan, sebagai ilmu normatif, "ilmu hukum mempunyai cara kerja yang unik dalam membantu memecahkan masalah hukum yang dihadapi masyarakat". Jenis penelitian yang digunakan menurut sifatnya adalah penelitian deskriptif, sesuai dengan tujuannya untuk mengetahui faktafakta bagaimana penerapannya dalam bidang ketentuan hukum normatif yang telah dibentuk oleh negara apakah telah didukung dengan kesiapan dari segi sarana dan prasarana. Dalam prakteknya, penelitian ini menitikberatkan pada masalah yaitu penelitian yang mengaitkan penelitian murni dengan penelitian terapan, dan menurut ilmu yang digunakan adalah penelitian monodisiplin, hanya berdasarkan satu disiplin ilmu yaitu hukum. Jenis data yang digunakan dalam penelitian ini adalah data yang terdiri dari bahan hukum primer, sekunder, dan tersier sebagai berikut. Bahan hukum primer dan sekunder dikumpulkan, kemudian dianalisis dan disajikan secara deskriptif kualitatif. Mengenai alat pengumpulan data, peneliti menggunakan studi dokumen ditambah wawancara dengan nara sumber, dalam hal ini dengan mendatangi langsung Lembaga Pemasyarakatan Kelas II B Cianjur untuk melengkapi data yang terkumpul. 


\section{HASIL ATAU PEMBAHASAN}

\section{Perlindungan Hukum Narapidana Wanita yang Mengandung di Dalam Lapas Kelas II B Cianjur}

Perlindungan hukum terhadap hak-hak narapidana perempuan dengan perlindungan hukum preventif, bentuk perlindungan ini adalah tindakan preventif yang dilakukan oleh petugas pemasyarakatan jika terjadi diskriminasi terhadap sesama narapidana adapun tindakan preventif seperti keamanan dan ketertiban sebagaimana diamanatkan undang-undang. Nomor 12 Tahun 1995 tentang Pemasyarakatan Pasal 46: Kepala lembaga pemasyarakatan bertanggung jawab atas keamanan dan ketertiban di lembaga pemasyarakatan yang dipimpinnya.

Pasal 5 Undang-Undang Nomor: 12 Tahun 1995 memuat prinsip penyelenggaraan lembaga pemasyarakatan di Indonesia berdasarkan:

a) Perlindungan; Ditujukan sebagai perlakuan bagi narapidana di lembaga pemasyarakatan dalam rangka melindungi masyarakat dari terulangnya tindak pidana yang dilakukan oleh narapidana dengan memberikan bekal hidup berupa keterampilan, pendidikan, pembinaan jasmani, rohani, dan keagamaan selama proses pemasyarakatan.

b) Kesetaraan perlakuan dan pelayanan; Semua narapidana diperlakukan dan dilayani sama tanpa memandang latar belakang mereka (Non Diskriminasi).

c) Pendidikan dan bimbingan; Ibadah ini dilandasi oleh penanaman semangat kekeluargaan, budi pekerti, pendidikan spiritual, kesempatan beribadah dan keterampilan berdasarkan Pancasila.

d) Penghormatan terhadap martabat manusia; Asas ini dijelaskan sebagai bentuk perlakuan terhadap narapidana yang dianggap hilang, tetapi harus diperlakukan sebagai manusia.

e) Kehilangan kebebasan adalah satu-satunya penderitaan; Hal ini dimaksudkan agar narapidana hanya ditempatkan sementara di lembaga pemasyarakatan untuk mendapatkan rehabilitasi dari negara. Seorang narapidana hanya kehilangan kebebasan bergerak, sehingga hak-hak sipilnya seperti pemeliharaan kesehatan, makanan dan minuman, sandang, olahraga, rekreasi, istirahat dan hak untuk tidak disiksa/dianiaya tetap dilindungi dan dipenuhi.

f) Jaminan hak untuk tetap berhubungan dengan keluarga dan orang-orang tertentu.

g) Sistem Pemasyarakatan adalah proses pembinaan narapidana berdasarkan prinsip Pancasila, yang memandang narapidana sebagai makhluk Tuhan, individu dan sekaligus sebagai anggota masyarakat. Dalam pembinaan narapidana dikembangkan kehidupan mental, fisik, pribadi dan sosial dan dalam pelaksanaannya terlibat langsung dan tidak melepaskan hubungan dengan masyarakat. 


\section{Upaya Pemenuhan Hak Narapidana Perempuan Hamil dan Pasca Melahirkan di Lembaga Pemasyarakatan Perempuan Kelas II B Cianjur}

Dalam upaya perlindungan hak asasi manusia di Lapas Khusus bagi perempuan hamil atau nifas, diperlukan perlakuan khusus bagi mereka. Lembaga pemasyarakatan diharapkan menjadi ujung tombak dalam penyelenggaraan dan perlindungan narapidana sehingga hak-hak mutlak dari narapidana itu sendiri dapat diberikan dengan baik. Penetapan blokir Perempuan di Lapas ditetapkan berdasarkan SK Kepala Kanwil Kemenkum HAM No. W20-17.OT.01.01 Tahun 2017. Serta struktur organisasinya dan tata kerja Lembaga Pemasyarakatan Kelas II B Cianjur diatur dalam Keputusan Menteri Kehakiman Nomor M.01.PR.07.03 Tahun 1985 tentang Organisasi dan Tata Kerja Lembaga Pemasyarakatan (Putri et al., 2021).

Pada dasarnya penyelenggaraan pelayanan kesehatan bagi narapidana khususnya ibu hamil dan nifas mengalami beberapa kendala dalam pendistribusiannya. Sesuai dengan hasil wawancara penulis dengan petugas kesehatan yang bertugas di Lembaga Pemasyarakatan Kelas II B Cianjur yang menyatakan bahwa alat pemeriksaan untuk memeriksa janin tidak lengkap, jumlah dokter kandungan yang bertugas kurang memadai, tata cara pelaporan kepada petugas sipir Rutan sebelum melakukan pemeriksaan terhadap narapidana.

\section{Pemenuhan Hak Pembinaan Terhadap Narapidana Wanita yang Mengandung di Lapas Kelas II B Cianjur}

a) Pembinaan Kepribadian

Program Pembinaan Kepribadian ini bertujuan untuk menumbuhkan kepercayaan dan kemampuan diri Narapidana, meningkatkan kualitas agar memiliki mental spiritual (agama) yang baik, taat menjalankan perintah agama, memiliki kesadaran hukum yang baik, dan memiliki kemampuan intelektual yang baik sehingga bisa kembali diterima oleh masyarakat setelah habis masa hukumannya. Pembinaan Kepribadian di Lembaga Pemasyarakatan Kelas II B Cianjur biasanya terdiri dari ceramah agama, pengajian Al-Qur'an, belajar pendidikan umum dan pengalaman pancasila. 
b) Pembinaan Kemandirian

Diterapkannya pembinaan kemandirian dengan tujuan agar terpidana mempunyai keahlian atau kecakapan teknis yang berguna bagi dirinya dan dapat dijadikan bekal ketika telah keluar dari Lembaga Pemasyarakatan. Secara umum program ini bertujuan untuk membentuk kemandirian manusia.

Untuk Narapidana perempuan yang hamil diperintahkan untuk tetap melaksanakan kewajibanya yang telah diprogramkan dalam pembinaan Narapidana, namun dalam melaksanakannya tidak seperti Narapidana wanita pada umumnya. Pembinaan terhadap Narapidana perempuan hamil di Lembaga Pemasyarakatan tetap disamakan dengan pembinaan terhadap Narapidana lain pada umumnya, namun memang ada kebutuhan yang harus di berikan untuk Narapidana perempuan hamil. Berdasarkan pada teori Pemidanaan, hukuman yang diberikan kepada Narapidana pada saat ini bertujuan untuk memperbaiki diri akibat kejahatan yang pernah dilakukan, sehingga jika narapidana sudah keluar dari Lapas maka dia dapat diterima kembali di masyarakat (Atmadja \& Budiartha, 2018). Pembinaan dari pihak Lembaga Pemasyarakatan tetap memberikan hakhak atas Narapidana yang hamil serta tetap memberikan kewajiban yang harus dipatuhi.

Adapun kewajiban-kewajiban yang ditetapkan oleh pihak Lembaga Pemasyarakatan sesuai dengan yang tercantum dalam Peraturan Mentri Hukum dan Hak Asasi Manusia RI Nomor 6 Tahun 2013 Tentang Tata Tertib Lembaga Pemasyarakatan dan Rumah Tahanan Pasal 3 yang berbunyi, "Setiap Narapidana atau Tahanan wajib:

1) Taat menjalankan ibadah sesuai agama dan/atau kepercayaan yang dianutnya serta memelihara kerukunan beragama

2) Mengikuti seluruh kegiatan yang di programkan

3) Patuh, taat dan hormat kepada petugas

4) Mengenakan pakaian seragam yang telah ditentukan

5) Memelihara kerapian diri dan lingkungan hunian serta mengikuti kegiatan yang dilaksanakan dalam rangka kebersihan lingkungan hunian, dan

6) Mengikuti apel kamar yang dilaksanakan oleh petugas pemasyarakatan.

Namun dari kewajiban-kewajiban tersebut, pihak Lembaga Pemasyarakatan telah memberikan keringanan atau toleransi kepada Narapidana wanita yang hamil untuk tidak melakukan semua kewajiban tersebut, seperti kegiatan rutinitas yang 
dilakukan setiap pagi yaitu apel kamar, olahraga yang rutinitas dilakukan oleh seluruh Narapidana pada setiap pagi, gotong royong dan kegiatan lain yang diprogramkan yang membahayakan kandungan itu tidak wajib bagi Narapidana wanita hamil untuk dilakukan. Akan tetapi kewajiban dari segi keagamaan yang termasuk dalam pembinaan kepribadian tetap wajib dilakukan oleh seluruh Narapidana, termasuk Narapidana yang hamil.

Kewajiban lain yang dimiliki Narapidana sesuai dengan Peraturan Mentri Hukum dan Hak Asasi Manusia RI Nomor 6 Tahun 2013 Tentang Tata Tertib Lembaga Pemasyarakatan dan Rumah Tahanan Pasal 3 huruf (b) yaitu, Narapidana wajib melaksanakan kegiatan yang diprogram oleh Lembaga Pemasyarakatan. Bahwa Di Lembaga Pemasyarakatan dalam pembinaan kemandirian menyediakan berbagai program kegiatan yang dapat dipekerjakan oleh Narapidana didalamnya. Adapun kegiatan-kegiatan tersebut adalah sebagai berikut: Membatik; Menjahit; Salon; Tata boga; Peternakan; Pertanian; Perikanan Sablon; Dan lain sebagainya (menyesuaikan kebijakan Lapas)

Dari berbagai macam kegiatan diatas Narapidana tersebut hanya dapat dipekerjakan sesuai dengan bakat kemampuannya. Untuk Narapidana perempuan hamil yang kandungannya masih dalam usia 1-5 bulan, dari pihak Lembaga Pemasyarakatan masih diperbolehkan untuk mengikuti kegiatan tersebut. Namun jika kandungan sudah memasuki usia 7 bulan keatas maka Narapidana wanita yang hamil tidak diwajibkan untuk melakukan pekerjaan tersebut, karena dikhawatirkan terhadap kondisi kandungan.

Begitu pula dengan hak-hak Narapidana perempuan yang hamil di Lembaga Pemasyarakatan pembinaan mereka tetap disamakan dengan Narapidana pada umumnya. Sebagaimana pelaksanaan hak narapidana perempuan yang terdapat dalam peraturan pemerintah Nomor 32 Tahun 1999 tentang Syarat dan Tata Cara Pelaksanaan Hak Warga Binaan Pemasyarakatan. Dimana dalam Pasal 20 mengatur perlindungan terhadap narapidana perempuan, yaitu : 1) Narapidana dan anak didik pemasyarakatan yang sakit, hamil dan menyusui berhak mendapat makanan tambahan sesuai dengan petunjuk dokter; 2) Makanan tambahan juga diberikan kepada narapidana yang melakukan pekerjaan jenis tertentu; 3) Anak dari narapidana wanita dibawa kedalam Lembaga Pemasyarakatan ataupun yang 
lahir di Lembaga Pemasyarakatan dapat diberi makanan tambahan atas petunjuk dokter, paling lama sampai berumur 2 tahun; 4) Dalam hal anak sebagaimana dimaksud dalam ayat 3 telah mencapai umur 2 tahun, harus diserahkan kepada sanak keluarganya; 5) Untuk kepentingan kesehatan anak, kepala Lembaga Pemasyarakatan dapat menentukan makanan tambahan.

Hak-hak diatas yang tertuang dalam peraturan pemerintah Nomor 32 Tahun 1999 tentang Syarat dan Tata Cara Pelaksanaan Hak Warga Binaan Pemasyarakatan menjelaskan bahwa bagi Narapidana yang sakit, hamil, menyusui, Narapidana yang mendapatkan pekerjaan tertentu serta anak dari Narapidana yang melahirkan mereka berhak mendapat makanan tambahan. Batas anak Narapidana mendapatkan makanan tambahan sampai anak tersebut berusia 2 tahun. Dan ketika anak sudah mencapai usia 2 tahun maka wajib diserahkan pada pihak keluarga.

Hak lain yang dimiliki oleh seorang Narapidana terdapat dalam Peraturan Pemerintah No 32 Tahun 1999 Pasal 5 Tentang syarat-syarat dan Tata Cara Pelaksanaan Hak Warga Binaan Pemasyarakatan, yang mengatur tentang hak yang dimiliki oleh setiap Narapidana dan anak didik pemasyarakatan untuk mendapat perawatan jasmani dan rohani. Dan pasal 14 ayat (1), setiap Narapidana dan anak didik pemasyarakatan berhak mendapatakan pelayanan kesehatan yang bagus.

\section{PENUTUP}

\section{Kesimpulan}

Perlindungan hukum terhadap hak-hak narapidana perempuan dengan perlindungan hukum preventif, bentuk perlindungan ini adalah tindakan preventif yang dilakukan oleh petugas pemasyarakatan jika terjadi diskriminasi terhadap sesama narapidana adapun tindakan preventif seperti keamanan dan ketertiban sebagaimana diamanatkan undang-undang.

Upaya Pemenuhan Hak Narapidana Perempuan Hamil dan Pasca Melahirkan di Lembaga Pemasyarakatan Perempuan Kelas II B Cianjur Dalam upaya perlindungan hak asasi manusia di Lapas Khusus bagi perempuan hamil atau nifas, diperlukan perlakuan khusus bagi mereka. Lembaga pemasyarakatan 
diharapkan menjadi ujung tombak dalam penyelenggaraan dan perlindungan narapidana sehingga hak-hak mutlak dari narapidana itu sendiri dapat diberikan dengan baik. Kendala yang Lembaga Pemasyarakatan Kelas II B Cianjur dalam menangani narapida Wanita yang mengandung adalah alat pemeriksaan untuk memeriksa janin yang tidak lengkap, jumlah dokter kandungan yang bertugas kurang tidak memadai.

Pemenuhan Hak Pembinaan Terhadap Narapidana Wanita yang Mengandung di Lapas Kelas II B Cianjur salah satunya adalah pembinaan kepribadian, program pembinaan kepribadian ini bertujuan untuk menumbuhkan kepercayaan dan kemampuan diri Narapidana, meningkatkan kualitas agar memiliki mental spiritual (agama) yang baik, taat menjalankan perintah agama, memiliki kesadaran hukum yang baik, dan memiliki kemampuan intelektual yang baik sehingga bisa kembali diterima oleh masyarakat setelah habis masa hukumannya.

Pembinaan dari pihak Lembaga Pemasyarakatan tetap memberikan hak-hak atas Narapidana yang hamil serta tetap memberikan kewajiban yang harus dipatuhi. Adapun kewajiban-kewajiban yang ditetapkan oleh pihak Lembaga Pemasyarakatan sesuai dengan yang tercantum dalam Peraturan Mentri Hukum dan Hak Asasi Manusia RI Nomor 6 Tahun 2013 Tentang Tata Tertib Lembaga Pemasyarakatan dan Rumah Tahanan Pasal 3 yang berbunyi, "Setiap Narapidana atau Tahanan wajib: Namun dari kewajiban-kewajiban tersebut, pihak Lembaga Pemasyarakatan telah memberikan keringanan atau toleransi kepada Narapidana wanita yang hamil untuk tidak melakukan semua kewajiban tersebut, seperti kegiatan rutinitas yang dilakukan setiap pagi yaitu apel kamar, olahraga yang rutinitas dilakukan oleh seluruh Narapidana pada setiap pagi, gotong royong dan kegiatan lain yang diprogramkan yang membahayakan kandungan itu tidak wajib bagi Narapidana wanita hamil untuk dilakukan. Akan tetapi kewajiban dari segi keagamaan yang termasuk dalam pembinaan kepribadian tetap wajib dilakukan oleh seluruh Narapidana, termasuk Narapidana yang hamil. Kewajiban lain yang dimiliki Narapidana sesuai dengan Peraturan Mentri Hukum dan Hak Asasi Manusia RI Nomor 6 Tahun 2013 Tentang Tata Tertib Lembaga Pemasyarakatan 
dan Rumah Tahanan Pasal 3 huruf (b) yaitu, Narapidana wajib melaksanakan kegiatan yang diprogram oleh Lembaga Pemasyarakatan.

Untuk Narapidana perempuan hamil yang kandungannya masih dalam usia 1-5 bulan, dari pihak Lembaga Pemasyarakatan masih diperbolehkan untuk mengikuti kegiatan tersebut. Namun jika kandungan sudah memasuki usia 7 bulan keatas maka Narapidana wanita yang hamil tidak diwajibkan untuk melakukan pekerjaan tersebut, karena dikhawatirkan terhadap kondisi kandungan. Begitu pula dengan hak-hak Narapidana perempuan yang hamil di Lembaga Pemasyarakatan pembinaan mereka tetap disamakan dengan Narapidana pada umumnya.

Sebagaimana pelaksanaan hak narapidana perempuan yang terdapat dalam peraturan pemerintah Nomor 32 Tahun 1999 tentang Syarat dan Tata Cara Pelaksanaan Hak Warga Binaan Pemasyarakatan yang menjelaskan bahwa bagi Narapidana yang sakit, hamil, menyusui, Narapidana yang mendapatkan pekerjaan tertentu serta anak dari Narapidana yang melahirkan mereka berhak mendapat makanan tambahan. Hak lain yang dimiliki oleh seorang Narapidana terdapat dalam Peraturan Pemerintah No 32 Tahun 1999 Pasal 5 Tentang syaratsyarat dan Tata Cara Pelaksanaan Hak Warga Binaan Pemasyarakatan, yang mengatur tentang hak yang dimiliki oleh setiap Narapidana dan anak didik pemasyarakatan untuk mendapat perawatan jasmani dan rohani. Dan pasal 14 ayat (1), setiap Narapidana dan anak didik pemasyarakatan berhak mendapatakan pelayanan kesehatan yang baik.

\section{Saran}

Dalam proses pemenuhan hak-hak narapidana di Lapas, pemerintah harus meninjau dan mengevaluasi secara berkala, apakah pelayanan yang diberikan oleh Lapas sudah sesuai dengan ketentuan undang-undang dan beberapa peraturan terkait. Sehingga narapidana yang sedang hamil dan setelah melahirkan mendapat pelayanan yang layak dan tidak mengganggu kesehatan janin dan ayakan narapidana itu sendiri. Pemerintah hendaknya lebih memperhatikan sumber daya manusia di setiap unit pelayanan teknis khususnya di Lembaga Pemasyarakatan Wanita Kelas II B Cianjur agar diberikan pelayanan dan fasilitas kesehatan bagi 
narapidana yang sedang hamil dan setelah melahirkan, sehingga mendapatkan kesehatan yang optimal dan efisien. pelayanan dalam penanganan.

\section{E. UCAPAN TERIMA KASIH}

Puji dan syukur saya panjatkan kepada Tuhan Yang Maha Esa yang berkat rahmat-Nya lah saya bisa menyelesaikan jurnal ini. Ucapan terimakasih tak lupa saya sampaikan kepada Bapak Mitro Subroto, Bc. IP., S.I.P., M. Si. Selaku Dosen pengampu Mata Kuliah Studi Kelompok Rentan yang telah membimbing saya dalam pembuatan jurnal ini, serta kepada keluarga dan rekan-rekan saya yang senantiasa memberikan bantuan dan dukungan kepada saya.

\section{F. DAFTAR PUSTAKA}

Atmadja, I. D. G., \& Budiartha, I. N. P. (2018). Teori-Teori Hukum. Setara Press. Fatony, A. (2015). Efektivitas Pelaksanaan Hak Warga Binaan Perempuan Dalam Mewujudkan Tujuan Pemasyarakatan: Studi Kasus Rumah Tahanan Klas IIA Jakarta Timur. Jurnal Hukum Dan Pembangunan, 45(3), 377-407.

Ismail Pettanase. (2019). Pembinaan Narapidana dalam Sistem Pemasyarakatan. Solusi, 17(1), 57-63.

Putri, D. K. R., Dewi, A. A. S. L., \& Ujianti, N. M. P. (2021). Peran Lembaga Pemasyarakatan Dalam Memenuhi Hak Narapidana Perempuan Hamil Dan Pasca Melahirkan (Studi Di Lembaga Pemasyarakatan Perempuan Kelas II A Kerobokan). Jurnal Interpretasi Hukum, 2(3), 550-554.

Ramadhani, M., Mahsyar, A., \& Usman, J. (2016). Pelaksanaan Program Pembinaan Narapidana Wanita di Lembaga Permasyarakatan Wanita Kelas IIA Sungguminasa. Jurnal Administrasi Publik, 2(3), 338-350.

Rusydi, Y. (2021). Pengawasan Terhadap Pemenuhan Hak-Hak Narapidana Di RUmah Tahanan Negara Kelas 1A Pakjo Palembang. Jurnal Hukum Samudra Keadilan, 16(2), 231-246.

Samosir, C. D. (2016). Penologi dan Pemasyrakatan. Nuansa Aulia.

Sulhin, I. (2010). Filsafat (Sistem) Pemasyarakatan. Jurnal Kriminologi Indonesia, 7(1), 134-150.

Sumarauw, Y. (2013). Narapidana Perempuan dalam Penjara (Suatu Kajian Antropologi Gender). HOLISTIK, Journal Of Social and Culture, VI(aa), 117.

Suwarto. (2007). Pelaksanaan Pidana Penjara dengan Sistem Pemasyarakatan. Jurnal Hukum Pro Justisia, 25(2), 166-177. 